\title{
Potential Uses of Copper Wastes in the Building Sector: Inertization and Added Value Solutions ${ }^{\dagger}$
}

\author{
Santiago Rosado ${ }^{1,2, *}$, Lidia Gullón ${ }^{2}$, Luis Felipe Mazadiego Martínez ${ }^{3}$ and Juan Francisco Llamas Borrajo ${ }^{3}$ \\ 1 Escuela Técnica Superior de Ingenieros de Minas y Energía, Universidad Politécnica de Madrid, \\ 28003 Madrid, Spain \\ 2 Fundación Gómez Pardo, 28003 Madrid, Spain; direccion.tecnica@fgomezpardo.es \\ 3 Departamento de Energía y Combustibles, Escuela Técnica Superior de Ingenieros de Minas y Energía, \\ Universidad Politécnica de Madrid, 28003 Madrid, Spain; luisfelipe.mazadiego@upm.es (L.F.M.M.); \\ juan.llamas@upm.es (J.F.L.B.) \\ * Correspondence: santiago.rosado@fgomezpardo.es \\ + Presented at International Conference on Raw Materials and Circular Economy, Athens, Greece, \\ 5-9 September 2021.
}

check for

updates

Citation: Rosado, S.; Gullón, L.; Martínez, L.F.M.; Llamas Borrajo, J.F. Potential Uses of Copper Wastes in the Building Sector: Inertization and Added Value Solutions. Mater. Proc. 2021, 5, 25. https://doi.org/ 10.3390/materproc2021005025

Academic Editor: Evangelos Tzamos

Published: 23 November 2021

Publisher's Note: MDPI stays neutral with regard to jurisdictional claims in published maps and institutional affiliations.

Copyright: (c) 2021 by the authors. Licensee MDPI, Basel, Switzerland. This article is an open access article distributed under the terms and conditions of the Creative Commons Attribution (CC BY) license (https:// creativecommons.org/licenses/by/ $4.0 /)$.

\begin{abstract}
Mining activity is the second biggest producer of waste in the European Union (EU), so to develop processes that allow the reuse of waste and the consequent creation of markets for these secondary raw materials are relevant for a desirable transition to a circular economy. Copper waste such as cakes, tailings, pyrite roasting residues, or slags present very different physical characteristics and hazards. There are two important aspects to consider for the residue of hazardous determination and its reuse: the particle size and the leaching behavior. Also, the reactive or non-reactive property of the waste depends on their origin, which is important for new applications. Based on these parameters (and other specifics for each application), the intention of this paper is to review and study the different applications of copper residues, aiming for new possibilities of cement-based construction materials with added value that allow to economically justify the use of cement.
\end{abstract}

Keywords: arsenic; copper wastes; cement; mortar; concrete

\section{Introduction}

In 2018, mining produced $635.5 \mathrm{Mt}$ of waste, which represents $24 \%$ of all waste produced in the European Union (EU). Only the construction sector presents a higher value, 37\% [1]. On the other hand, copper mining estimates that 1 ton of copper metal production generates about 130 tons of mining and metallurgical waste (tailings and slags) [2].

Despite the fact that Directive 2006/21/EC [3] has served to add pressure to this sector, there is still room for improvement in the regulatory aspect of construction materials in mining operations since currently all this waste is treated and deposited in the mining area [4] with subsequent integration in the environmental restoration plan. On the other side, an increase in the use of mining waste in the construction sector may contribute positively to the decrease in the consumption of raw materials by this sector.

These practices have already been carried out in very different ways. The use of copper tailings as a filler for the mining chambers, known as cemented paste backfill, is the most common one [5]. This technology contemplates the filling of mining chambers with a paste composed of copper tailings together with a hydraulic binder in low proportions to provide some additional structural integrity. On the contrary, the use of the copper tailings as a filling aggregate (for the construction sector) is no frequently considered due to the need to stabilize the waste to reduce its danger [6]. Therefore, investigations to apply in mortars [7-9], concretes [10-13], and ceramic products $[4,14,15]$ have been more frequent. Another option is the inclusion in geopolymer mixtures [16-18], which are materials bound 
with a material rich in aluminum oxides and silicates capable of developing resistance when activated with an alkaline solution. These can be metakaolin, fly ash, or slag [19]. This option has been extensively studied since it is shown as a potential alternative to ordinary Portland cement [20]. In addition, there is the possibility of partially or totally substituting cement and/or aggregates by other types of waste or different natural materials to obtain a product called composite [21,22] that, despite not meeting the standards required by European legislation relating to construction materials, it has a good physical, chemical, and mechanical behavior.

All these applications have a double purpose. On one hand, they intend to inert or stabilize the pollutants present in the waste, and on the other hand, to develop a new construction material.

The fixation of copper residues has already been studied and has been applied for years on an industrial scale. The main objective is to reduce the danger of waste and increase its chemical stability. In general, precipitation processes with additions of lime, iron, or sulphides are used [23] when the streams present pollutants in solution. In case of solid waste, cement can be used as a form of encapsulation proven as effective, but presents a high cost and high carbon footprint (derived from cement production) [24].

The use of copper waste as construction material has two great advantages that will drive the growth of this practice in the coming years: it reduces the consumption of primary raw materials for construction material manufacturing and allows the valorization of the copper waste as a secondary raw material in construction applications. On the contrary, there is a great disadvantage: the extensive European regulations on construction materials limiting the use of this kind of waste in order to maintain high quality standards; not because of its origin but partly because of its composition and mainly because of its properties.

This paper aims to review the requirements of different construction materials according to the regulations, without going into depth in the different applications of each material in particular, with the aim of determining the essential requirements, the greatest barriers and solutions, addressing the potential evolution of each material.

\section{General Characteristics of Copper Waste}

In general, copper mining waste is divided into several large groups (Figure 1): inert waste from exploitation, tailings [25], and pyrometallurgy products [26]. Inert waste already has an internal reuse route and they are currently used for the construction of roads and dams or as filling aggregates.

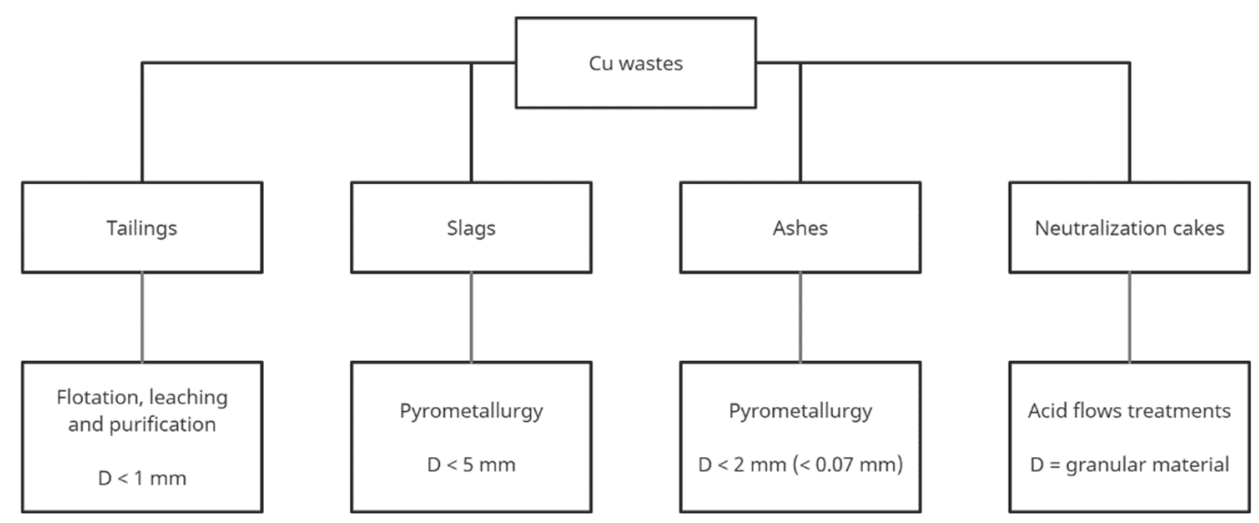

Figure 1. General classification of copper mining waste.

Tailing is the waste generated in the concentration of copper, either through flotation or leaching and purification processes. In the case of flotation residues, these have high amounts of silicon and iron and less, yet more variable amounts of aluminum, calcium, zinc, lead, copper, magnesium, potassium, and contaminants such as arsenic or bismuth [27-30]. The particle size depends on many factors and is a characteristic studied to optimize both 
flotation and leaching, but for the purposes of construction materials it can be accepted as less than $1 \mathrm{~mm}$ [11].

The copper concentrated by flotation is usually treated by pyrometallurgy generating three types of waste: cakes, slag, and dust. Slag is the main waste from smelters and its composition depends on the origin and composition of the mixture of concentrates used to feed the furnace, as well as the reagents and fluxes used in the process. In general, they are made up of iron silicate with lower amounts of aluminum, calcium, magnesium, potassium, etc. [31-37]. Its particle size is less than $5 \mathrm{~mm}$ [27,38]. Although the dust is recovered in much smaller amounts compared to the previous residues, they are of great importance. On the one hand, many of the toxic elements are recovered in the dust collected from the furnace gas stream because they volatilize during the melting process. On the other hand, its size is very small (microns), which makes it a health and environmental risk. Dusts are mainly composed of oxides and sulfides of lead, zinc, iron, tin, copper, and arsenic [39]. It is common for the furnace gas stream to be washed with water, allowing the generation of sulfuric acid and recovering of some of the recoverable metals [26,39-42]. In such a case, an acid stream with valuable metals and also with dangerous compounds (As) are set with lime, carbonates, sulfides, iron, or cement as already explained.

Furthermore, in Spain, a concentration system by roasting pyrites was common in the 19th century. These residues are currently being investigated for exploitation assessment. They have very diverse compositions based on silicon, iron, copper, sulfides, and lead, but with high amounts of arsenic. The particle size is always less than $2 \mathrm{~mm}$ [43].

Therefore, four types of copper waste to be reviewed can be established: (I) tailings with sizes smaller than $1 \mathrm{~mm}$ and with large amounts of contaminants, (II) smelter slags smaller than $5 \mathrm{~mm}$ with contaminants to a lesser degree than the previous one, (III) smelting or roasting ashes and powders with sizes smaller than $2 \mathrm{~mm}$ and typically smaller than 70 microns. (IV) neutralization cakes formed mainly by gypsum and metallic oxyhydroxides as a result of the treatment of acid currents. The latter usually have sizes greater than several $\mathrm{cm}$, but once in contact with water and in the mixer, they behave like a granular material.

\section{Definitions and Requirements of Concretes and Mortars}

The definition in Europe of construction products and their characteristics is given by regulations. Specifically, by EN 206 for concrete [44] and EN 998-1 or EN 998-2 for mortars depending on their application $[45,46]$.

Concretes are made up of cement, fine and coarse aggregate, admixtures, additives, fibers, and steel bars or meshes. The last three are far from the scope of this study because they are structural materials with high requirements. The mortars have the same composition than concretes, but without coarse aggregate and, furthermore, the proportions are not the same.

The role of cement in both products is fundamental since it is the material that acts as a binder. However, while the cement in concrete must meet certain requirements under EN 197-1 [47] for mortars there are no such requirements. This standard perfectly defines the components of cement and for years already includes some type of residue or by-product as a replacement for clinker: slag coming from iron processing and fly ashes coming from thermal centrals fed with coal.

In case of aggregates, it happens in the same way: aggregates in concrete applications must comply with the regulations given in EN 12620 [48], while in mortar applications in general it is enough to declare the aggregate grain size. This standard establishes requirements at three levels: geometric, physical, and chemical.

In the first requirement, the particle size distribution is determinant. In general, the regulation differences fine aggregates $(0-4 \mathrm{~mm})$ and coarse aggregates $(>4 \mathrm{~mm})$, but there are also requirements regarding their distribution (Table 1): 
Table 1. Particle size distribution requirements for concrete manufacturing.

\begin{tabular}{ccccccc}
\hline & Size & 2D $^{\mathbf{1}}$ & $\mathbf{1 . 4 D}$ & $\mathbf{D}$ & $\mathbf{d}$ & $\mathbf{d} / \mathbf{2}$ \\
\hline \multirow{3}{*}{ Coarse aggregate } & $\mathrm{D} / \mathrm{d}<2$ or $\mathrm{D}<11.2$ & 100 & $98-100$ & $85-99$ & $0-20$ & $0-5$ \\
& $\mathrm{D} / \mathrm{d}>2$ or $\mathrm{D}>11.2$ & 100 & $98-100$ & $85-99$ & $0-20$ & $0-5$ \\
Fine aggregate & $\mathrm{D}<4 \mathrm{~mm}$ and $\mathrm{d}=0$ & 100 & $98-100$ & $90-99$ & $0-15$ & $0-5$ \\
Mixed & $\mathrm{D}<45 \mathrm{~mm}$ and $\mathrm{d}=0$ & 100 & $98-100$ & $85-99$ & - & - \\
& & 100 & $98-100$ & $85-99$ & - & - \\
\hline
\end{tabular}

${ }^{1}$ Where " $\mathrm{D}$ " is the largest particle size and " $\mathrm{d}$ " the lowest.

The physical requirements are important, but not decisive to discard the use of the waste as aggregate. This depends on its final application. However, it is noteworthy that the composition of recycled aggregates is measured visually, differentiating between concrete, aggregate, baked clay, asphalt, glass, and others.

The same is true for chemical requirements. They are not decisive to discard the use of a mining waste as aggregate, since this will depends on the final application.

Additions in the manufacture of concrete are more regulated, while for mortars there is freedom of use. In the first case, the additions can be certain residues (fly ash, silica fume, or granular slags) that cannot be modified or they can be pigments or fines for which there are no requirements other than those set by the manufacturer itself, although the recommendation is to usually limit them to $3 \%$ because these materials can be similar to the mineral filler.

Finally, the environmental aspect deserves separate consideration. Many of these wastes contain potentially dangerous elements such as $\mathrm{As}, \mathrm{Ba}, \mathrm{Cd}$, or $\mathrm{Hg}$ and their application is limited by the values they present in leaching [49] (Table 2). In Europe, the values defined by the waste dumping regulations are taken as a reference and it is established that if it does not exceed the limitation imposed for inert waste, there should be no contamination.

Table 2. Leaching limits for inert residues.

\begin{tabular}{|c|c|c|}
\hline Component & $\begin{array}{l}\text { Leaching Test (L/S = } 10 \mathrm{~L} / \mathrm{kg}) \\
(\mathrm{mg} / \mathrm{kg} \text { Dry Matter })\end{array}$ & Percolation (mg/L) \\
\hline As & 0.5 & 0.06 \\
\hline $\mathrm{Ba}$ & 20 & 4 \\
\hline $\mathrm{Cd}$ & 0.04 & 0.02 \\
\hline Cr total & 0.5 & 0.1 \\
\hline $\mathrm{Cu}$ & 2 & 0.6 \\
\hline $\mathrm{Hg}$ & 0.01 & 0.002 \\
\hline Mo & 0.5 & 0.2 \\
\hline $\mathrm{Ni}$ & 0.4 & 0.12 \\
\hline $\mathrm{Pb}$ & 0.5 & 0.15 \\
\hline $\mathrm{Sb}$ & 0.06 & 0.1 \\
\hline Se & 0.1 & 0.04 \\
\hline $\mathrm{Zn}$ & 4 & 1.2 \\
\hline Chlorides & 800 & 460 \\
\hline Fluorides & 10 & 2.5 \\
\hline Sulphates & 1000 & 1500 \\
\hline Phenol index & 1 & 0.3 \\
\hline DOC $^{1}$ & 500 & 160 \\
\hline $\mathrm{TDS}^{2}$ & 4000 & \\
\hline
\end{tabular}

${ }^{1}$ Dissolved Organic Carbon. ${ }^{2}$ Total Dissolved Solids.

Therefore, according to European regulations, copper mining waste has the potential to replace part of the cement and act as a hydraulic binder, either as an aggregate or as an addition. In mortars, there is freedom to add copper residues in any aspect, but in concrete 
certain limits in terms of particle size distribution must be respected. In both cases, its application will depend on the leaching values.

On the other hand, obviously the use of these materials depends on the particular application that is regulated by the regulations of each country or even region. However, this is far from the purpose of this study. Here, it is intended to show the possibilities for the manufacture of materials. Its potential application will depend on each area.

\section{Discussion: Issues and Possible Solutions}

\subsection{Cement}

In general terms, copper waste has not been as widely studied as cement addition or other wastes from other industries (blast furnace slag, fly ash, or silica fume). This is because the composition of copper residues is not prone to improve the characteristics of the final products and also due to the contaminants within the residue that are not quantitative predominant but qualitative. Elements such us $\mathrm{As}, \mathrm{Hg}$, or $\mathrm{Pb}$ may add a hazardous characteristic to the new product. In fact, the mixture of these residues with cement has been applied as a fixation method in hazardous wastes [50-57].

In case of concrete manufacturing, mining and industrial copper waste is not included as allowed addition into cements, so their use is forbidden in the EU.

The potential uses of the copper residues in mortars manufacturing are higher than in concrete manufacturing. The cement additions should be limited by technical issues or requirements (mechanical behavior, durability, and toxicity) but not by the standards.

In general, the additions with high quantities of calcium $(\mathrm{CaO})$ or silica $\left(\mathrm{SiO}_{2}\right)$ are positives. Calcium has hydraulic properties so its addition does not damage the mechanical properties of the final product. The silica behavior is more complex and it is related with pozzolanic activity. The silica must be reactive, meaning the silica must be able to form new chemical compounds with the cement, reaching a better resistance in the long term. This reactivity of the silica is related with the stability of the formed compounds: as higher stability of the compound (such us quartz), less reactivity will be presented.

Tailings may include high amounts of silica, but usually as silicates. Reactive silica is added to cement with the aim to reach calcium silicates thanks to the cement hydration reactions. However, the addition of these silicates before cement hydration will not provide better properties.

The slags from copper smelters consists mainly on ferric silicate, which can be used as pozzolanic if the silica is reactive. This depends on the silica composition, but can be activated through a thermic treatment. The limitation here is due to the costs of the thermic treatment and the advantages should be many to justify the price. In any case, the cement substitution by slags or tailings will be lower than $20 \%$.

The addition of ashes coming from roasting in the cement manufacturing is not considered because the ashes content of metallic oxides and sulphur are detrimental to the properties of the final material. Neutralization cakes have a very high amounts of calcium but as gypsum which usually affects to the durability of the final product However, it can be added in low quantities (5\%) as setting regulator instead of natural gypsum. The substitutions of cement have been studied more in concrete manufacturing than in mortar manufacturing. Tailings with high amounts of silica $(>75 \%)$ and low amounts of calcium $(<10 \%)$ were mixed with cements in low proportions $(<5 \%)$ obtaining good values, $42.5 \mathrm{~N}$ (compressive strength) [58]. Others tailings and two different neutralization cakes with low content in silica $(28,11$, and $15 \%$ respectively) and calcium $(25,55$, and $43 \%$ respectively) were used in low proportions mixed with other wastes to obtain a mix with a content of $13-14 \%$ of silica and $41-42 \%$ of calcium [59]. The results show how it can be an alternative if the mix is burned with the clinker. Other different wastes with silica $(11.2 \%)$ and iron (85.3\%) were added to a concrete (5-10\%), obtaining better mechanical strengths [19].

On the other hand, the leaching behavior of the copper tailings has been assessed. The leaching value of the As is important because it is the main contaminant (due to their mobility and abundance), although others elements can also affect it. Cement addition is a 
good technique to fix As so the substitution of cement by wastes in cement-based products is a convenient application. Very good results (in terms of leaching) have been achieved with substitution of 50 [50], 16 [54], 10 [55], 32, or 53\% [56] of cement by wastes with high amount of As (1-32\%).

Based on the bibliography, low grade substitutions of tailings or slags by cement in mortars are feasible. Although the properties may be lower, the cement process will be cheaper. Sulphur and contaminant addition should be limited.

The copper residues should be treated before recycling. Depending on the copper residue, a milling process can be required to obtain a particle size lower than $70 \mu \mathrm{m}$. Slags are a very resistant material, which may cause an increment in the costs. Tailings are much easier to mill, but the drying process may be required.

\subsection{Aggregates}

Most copper residues have fine or very fine particle size, so it is not easy to use them as coarse aggregates. Only slags may be used if they are mixed with natural aggregates (or other recycled aggregate) in order to obtain the appropriate particle size distribution. Neutralization cakes can be used as coarse aggregate applying just a simple crushing treatment, but due to their nature the particles have a very low resistance (gypsum) to be part of a concrete. In addition, the final product will have durability issues due to the sulphur content. So, it is recommended not to use copper waste as coarse aggregates.

For fine aggregates there is more flexibility. Only concretes have particle size requirements and they can be reached in a simple way. However, fillers $(<80 \mu \mathrm{m})$ negatively affect the solidification so they should be limited to $3 \%$. As has already explained, neutralization cakes are not good aggregates, so the application limit should be $1.5 \%$ for concrete manufacturing and 5\% for mortar manufacturing.

Tailings with medium-high grain size and slags may require a crushing and sieving treatment to obtain fine aggregates. For the residues' application in concrete manufacturing there are some requirements about the distribution, but for mortar manufacturing more flexibility is accepted. As orientation, the standard sand has a maximum size (D) of $2 \mathrm{~mm}$ meanwhile other very common $\mathrm{D}$ are $4 \mathrm{~mm}$, which is the recommended grain size for aggregates application.

Figure 2 shows the particle size distribution of the normalized sand used in mortars manufacturing and the acceptable limits for the concrete manufacturing. This size distribution is not necessarily the most appropriate to obtain the best results, but just a reference understanding that very high deviations will negatively affect the final product anyway.

The use of aggregates with sulphur (with similar composition than copper tailings) to substitute both coarse and fine aggregates in concrete manufacturing has been studied [13]. Compressive strength shows that complete substitutions provide competitive results compared with the standard products. Slags have been also studied as a substitution of the fine fraction [8] of the aggregates. For substitutions up to $80 \%$, the compressive strength obtained is the same as the one presented in the standard materials. In mortars with complete substitution, slags provide better properties than natural sand [9].

On the other hand, the environmental aspect of the aggregates manufactured with copper residues is relevant because all copper wastes would leach and their use will be restricted (except slags, which are stables). Consequently, copper wastes provide better alternatives if they are used in cement-based materials and commercialized as final products: concrete and/or mortar. These final products will be marketable, if the suitability, non-toxicity, and stability of the final products are demonstrated within detailed leaching studies. This is the key concept to reuse copper wastes as aggregates: to market the final products. 


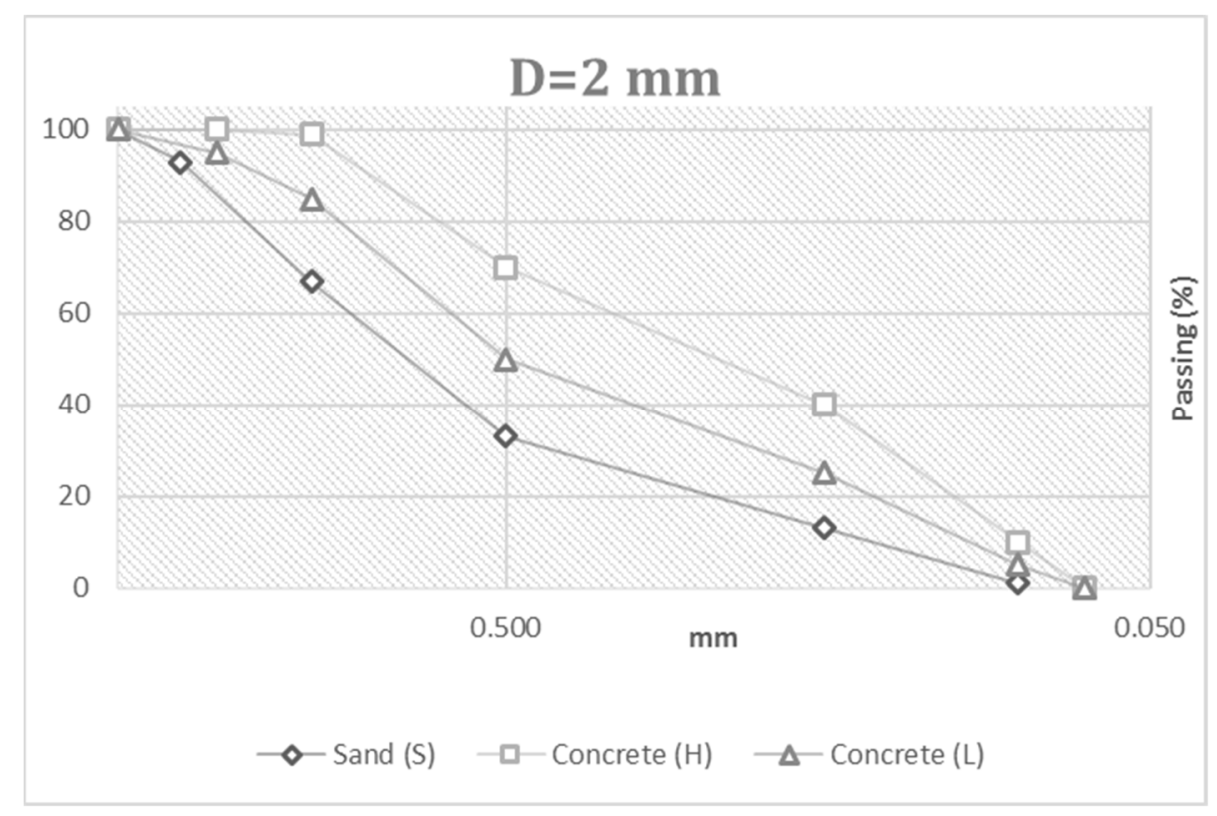

Figure 2. Particle size distribution of normalized sand, and the high and low limits for concrete.

In the previous section, the fixation of the toxic elements have discussed. In the aggregates case, the situation is similar: cement contributes positively to reducing the hazard of wastes. However, it should be considered that the total amount of arsenic in the cement-aggregates mixtures will be higher due to the greater proportion of aggregates than cement both in the manufacture of mortars and in the manufacture of concrete. Although there are some positive results such as the slags without leaching behavior, even long-term results, there is still a need to evaluate each final product designed.

\section{Conclusions}

The main conclusion is that the possibilities of adding copper residues (Figure 3) are more restricted in concrete manufacturing than in mortars manufacturing and the use of mortars is also restricted (it is not possible to make pieces with mortar such us curbs or pavers). Copper waste is suitable to be used as a substitute for cement only for mortars for manufacturing. As substitute of fine aggregates, they can be used in both mortars and concrete (with some restrictions). The application should be in final products instead of aggregates.

Tailings and slags can be used as cement addition or as aggregate depending of the particle size and the crushing treatment. If particle size is lower than $80 \mu \mathrm{m}$, the use in cement $(<20 \%)$ is recommended instead of in aggregates $(<3 \%)$. If the particle size is higher, the suggestion is to use fine aggregates in concrete and mortars. Slags are especially good as aggregates due to their resistance.

Ashes has lower uses. In cement, they will not provide improvements, but can be used in mortars $(<20 \%)$ with the aim of obtaining a cheaper product. As filler in fine aggregate, it is not recommended, but it can be used $(<3 \%)$.

Neutralization cakes can be a good option as solidification regulator $(<5 \%)$ instead of natural gypsum. This is a better option than substitution of aggregates for concrete $(<1.5 \%)$ or mortar manufacturing $(<5 \%)$.

In all cases, the leaching behavior should be studied. Several technics can be applied in the case of hazardous elements presence out of the limits, but the easiest solution is to limit the waste proportion to be added in the final product. 


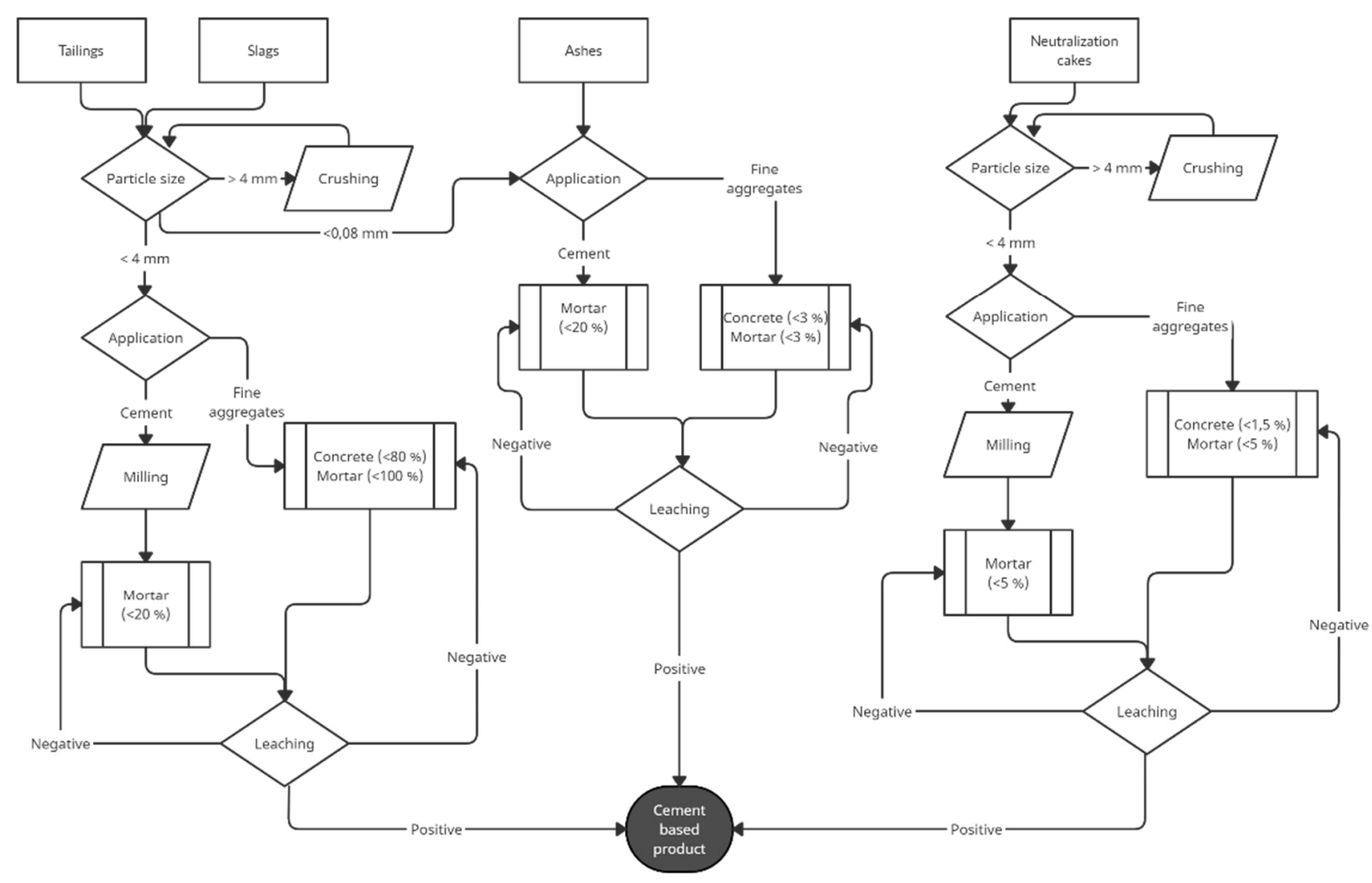

Figure 3. Decision tree for the use of copper residues in cement-based materials.

Although the use of copper waste in building materials in the EU is not excessively restricted, the main issue is the final application. Some wastes can be used in concrete manufacturing, but the regulations of the final application usually demand additional properties that residues rarely meet. Mortar manufacturing is a better option for copper residue recycling, but the issue is that mortar pieces are not commonly manufactured. Mortar is only used to fix ceramic pieces (masonry) or as a plaster. If mortar pieces similar to those of non-structural concrete can be manufactured, the applications would be greater. A good solution for the copper residues recycling is the development of new materials that are neither concrete nor mortar, but based on cement and are used in precast pieces without structural purposes such as pavers.

Funding: This research was funded by RIS-CuRe project PN 18248. Supported by EIT RawMaterials co-funded by the European Union.

\section{References}

1. Overview-Waste-Eurostat Disponible, en. Available online: https://ec.europa.eu/eurostat/web/waste/overview (accessed on 13 May 2021).

2. Gordon, R.B. Production residues in copper technological cycles. Resour. Conserv. Recycl. 2002, 36, 87-106. [CrossRef]

3. European Council. Directive 2006/21/EC of the European Parliament and of the Council of 15 March 2006 on the Management of Waste from Extractive Industries and Amending Directive 2004/35/EC; Official Journal of the European Union; European Union: Brussels, Belgium, 2006.

4. Kinnunen, P.; Ismailov, A.; Solismaa, S.; Sreenivasan, H.; Räisänen, M.L.; Levänen, E.; Illikainen, M. Recycling mine tailings in chemically bonded ceramics-A review. J. Clean. Prod. 2018, 174, 634-649. [CrossRef]

5. Qi, C.; Fourie, A. Cemented paste backfill for mineral tailings management: Review and future perspectives. Miner. Eng. 2019, 144, 106025. [CrossRef]

6. de Bastos, L.A.C.; Silva, G.C.; Mendes, J.C.; Peixoto, R.A.F. Using Iron Ore Tailings from Tailing Dams as Road Material. J. Mater. Civ. Eng. 2016, 28, 04016102. [CrossRef] 
7. Cristelo, N.; Coelho, J.; Oliveira, M.; Consoli, N.C.; Palomo, Á.; Fernández-Jiménez, A. Recycling and application of mine tailings in alkali-activated cements and mortars-strength development and environmental assessment. Appl. Sci. 2020, 10, 2084. [CrossRef]

8. Al-Jabri, K.S.; Al-Saidy, A.H.; Taha, R. Effect of copper slag as a fine aggregate on the properties of cement mortars and concrete. Constr. Build. Mater. 2011, 25, 933-938. [CrossRef]

9. Panda, S.; Sarkar, P. Leaching behavior of copper slag aggregate cement-mortar by atomic absorption spectroscopy (AAS). Mater. Today Proc. 2020, 33, 5123-5129. [CrossRef]

10. Muleya, F.; Mulenga, B.; Zulu, S.L.; Nwaubani, S.; Tembo, C.K.; Mushota, H. Investigating the suitability and cost-benefit of copper tailings as partial replacement of sand in concrete in Zambia: An exploratory study. J. Eng. Des. Technol. 2020. [CrossRef]

11. Gou, M.; Zhou, L.; Then, N.W.Y. Utilization of tailings in cement and concrete: A review. Sci. Eng. Compos. Mater. 2019, 26, 449-464. [CrossRef]

12. Fisonga, M.; Wang, F.; Mutambo, V. Sustainable utilization of copper tailings and tyre-derived aggregates in highway concrete traffic barriers. Constr. Build. Mater. 2019, 216, 29-39. [CrossRef]

13. Benarchid, Y.; Taha, Y.; Argane, R.; Tagnit-Hamou, A.; Benzaazoua, M. Concrete containing low-sulphide waste rocks as fine and coarse aggregates: Preliminary assessment of materials. J. Clean. Prod. 2019, 221, 419-429. [CrossRef]

14. Jordán, M.M.; Montero, M.A.; Pardo-Fabregat, F. Technological behaviour and leaching tests in ceramic tile bodies obtained by recycling of copper slag and MSW fly ash wastes. J. Mater. Cycles Waste Manag. 2021, 23, 707-716. [CrossRef]

15. Zhang, L. Production of bricks from waste materials-A review. Constr. Build. Mater. 2013, 47, 643-655. [CrossRef]

16. Sheikhhosseini Lori, I.; Toufigh, M.M.; Toufigh, V. Improvement of poorly graded sandy soil by using copper mine tailing dam sediments-based geopolymer and silica fume. Constr. Build. Mater. 2021, 281, 122591. [CrossRef]

17. Ahmari, S.; Zhang, L. Production of eco-friendly bricks from copper mine tailings through geopolymerization. Constr. Build. Mater. 2012, 29, 323-331. [CrossRef]

18. Ahmari, S.; Zhang, L. Utilization of cement kiln dust (CKD) to enhance mine tailings-based geopolymer bricks. Constr. Build. Mater. 2013, 40, 1002-1011. [CrossRef]

19. Solouki, A.; Viscomi, G.; Lamperti, R.; Tataranni, P. Quarry waste as precursors in geopolymers for civil engineering applications: A decade in review. Materials 2020, 13, 3146. [CrossRef]

20. Samarakoon, M.H.; Ranjith, P.G.; Rathnaweera, T.D.; Perera, M.S.A. Recent advances in alkaline cement binders: A review. J. Clean. Prod. 2019, 227, 70-87. [CrossRef]

21. Liu, J.; Guo, R.; Shi, P.; Huang, L. Hydration mechanisms of composite binders containing copper slag at different temperatures. J. Therm. Anal. Calorim. 2019, 137, 1919-1928. [CrossRef]

22. Liu, S.; Li, Q.; Zhao, X. Hydration kinetics of composite cementitious materials containing copper tailing powder and graphene oxide. Materials 2018, 11, 2499. [CrossRef] [PubMed]

23. Ostermeyer, P.; Bonin, L.; Folens, K.; Verbruggen, F.; García-Timermans, C.; Verbeken, K.; Rabaey, K.; Hennebel, T. Effect of speciation and composition on the kinetics and precipitation of arsenic sulfide from industrial metallurgical wastewater. J. Hazard. Mater. 2021, 409, 124418. [CrossRef]

24. Li, J.S.; Chen, L.; Zhan, B.; Wang, L.; Poon, C.S.; Tsang, D.C.W. Sustainable stabilization/solidification of arsenic-containing soil by blast slag and cement blends. Chemosphere 2021, 271, 129868. [CrossRef]

25. Henne, A.; Hamilton, J.; Craw, D.; Paterson, D.; Southam, G. The influence of metal mobility on resource potential in circumneutral $\mathrm{pH}$ iron-rich copper mine waste rocks. J. Geochem. Explor. 2020, 219, 106632. [CrossRef]

26. Mikula, K.; Izydorczyk, G.; Skrzypczak, D.; Moustakas, K.; Witek-Krowiak, A.; Chojnacka, K. Value-added strategies for the sustainable handling, disposal, or value-added use of copper smelter and refinery wastes. J. Hazard. Mater. 2021, 403, 123602. [CrossRef]

27. Karamanov, A.; Aloisi, M.; Pelino, M. Vitrification of copper flotation waste. J. Hazard. Mater. 2007, 140, 333-339. [CrossRef] [PubMed]

28. Mikoda, B.; Gruszecka-Kosowska, A. Mineral and chemical characteristics, textural parameters, and the mobility of the selected elements of flotation waste, originating from the Polish copper-mining industry. Hum. Ecol. Risk Assess. 2018, 24, 1216-1232. [CrossRef]

29. Liu, D.G.; Min, X.B.; Ke, Y.; Chai, L.Y.; Liang, Y.J.; Li, Y.C.; Yao, L.W.; Wang, Z.B. Co-treatment of flotation waste, neutralization sludge, and arsenic-containing gypsum sludge from copper smelting: Solidification/stabilization of arsenic and heavy metals with minimal cement clinker. Environ. Sci. Pollut. Res. 2018, 25, 7600-7607. [CrossRef]

30. Çoruh, S.; Ergun, O.N.; Cheng, T.W. Treatment of copper industry waste and production of sintered glass-ceramic. Waste Manag. Res. 2006, 24, 234-241. [CrossRef]

31. Fuentes, I.; Ulloa, C.; Jiménez, R.; García, X. The reduction of Fe-bearing copper slag for its use as a catalyst in carbon oxide hydrogenation to methane. A contribution to sustainable catalysis. J. Hazard. Mater. 2020, 387, 121693. [CrossRef]

32. Gupta, N.; Siddique, R. Durability characteristics of self-compacting concrete made with copper slag. Constr. Build. Mater. 2020, 247, 118580. [CrossRef]

33. Shi, G.; Liao, Y.; Su, B.; Zhang, Y.; Wang, W.; Xi, J. Kinetics of copper extraction from copper smelting slag by pressure oxidative leaching with sulfuric acid. Sep. Purif. Technol. 2020, 241, 116699. [CrossRef] 
34. Arslan, C.; Arslan, F. Recovery of copper, cobalt, and zinc from copper smelter and converter slags. Hydrometallurgy 2002, 67, 1-7. [CrossRef]

35. Maweja, K.; Mukongo, T.; Mutombo, I. Cleaning of a copper matte smelting slag from a water-jacket furnace by direct reduction of heavy metals. J. Hazard. Mater. 2009, 164, 856-862. [CrossRef]

36. Miganei, L.; Gock, E.; Achimovičová, M.; Koch, L.; Zobel, H.; Kähler, J. New residue-free processing of copper slag from smelter. J. Clean. Prod. 2017, 164, 534-542. [CrossRef]

37. Vítková, M.; Ettler, V.; Mihaljevič, M.; Šebek, O. Effect of sample preparation on contaminant leaching from copper smelting slag. J. Hazard. Mater. 2011, 197, 417-423. [CrossRef] [PubMed]

38. Pérez-Moreno, S.M.; Gázquez, M.J.; Ruiz-Oria, I.; Ríos, G.; Bolívar, J.P. Diagnose for valorisation of reprocessed slag cleaning furnace fl ue dust from copper smelting. J. Clean. Prod. 2018, 194, 383-395. [CrossRef]

39. Grudinsky, P.I.; Dyubanov, V.G.; Kozlov, P.A. Copper Smelter Dust Is a Promising Material for the Recovery of Nonferrous Metals by the Waelz Process. Inorg. Mater. Appl. Res. 2019, 10, 496-501. [CrossRef]

40. Qiang, L.; Pinto, I.S.S.; Youcai, Z. Sequential stepwise recovery of selected metals from flue dusts of secondary copper smelting. J. Clean. Prod. 2014, 84, 663-670. [CrossRef]

41. Chen, Y.; Liao, T.; Li, G.; Chen, B.; Shi, X. Recovery of bismuth and arsenic from copper smelter flue dusts after copper and zinc extraction. Miner. Eng. 2012, 39, 23-28. [CrossRef]

42. Morales, A.; Cruells, M.; Roca, A.; Bergó, R. Treatment of copper flash smelter flue dusts for copper and zinc extraction and arsenic stabilization. Hydrometallurgy 2010, 105, 148-154. [CrossRef]

43. López-Arce, P.; Garrido, F.; García-Guinea, J.; Voegelin, A.; Göttlicher, J.; Nieto, J.M. Historical roasting of thallium- and arsenic-bearing pyrite: Current Tl pollution in the Riotinto mine area. Sci. Total Environ. 2019, 648, 1263-1274. [CrossRef] [PubMed]

44. UNE-EN 206:2013+A1:2018 Hormigón. Especificaciones, Prestacion ... . Available online: https:/ /www.une.org/encuentra-tunorma/busca-tu-norma/norma/?c=N0060253 (accessed on 24 May 2021).

45. UNE-EN 998-1:2018 Especificaciones de los Morteros para albañi ... . Available online: https:/ / www.une.org/encuentra-tunorma/busca-tu-norma/norma?c=N0059828 (accessed on 24 May 2021).

46. UNE-EN 998-2:2018 Especificaciones de los Morteros para albañi ... . Available online: https://www.une.org/encuentra-tunorma/busca-tu-norma/norma?c=N0060256 (accessed on 24 May 2021).

47. UNE-EN 197-1:2011 Cemento. Parte 1: Composición, Especificacio ... . Available online: https://www.une.org/encuentra-tunorma/busca-tu-norma/norma?c=N0048623 (accessed on 24 May 2021).

48. UNE-EN 12620:2003+A1:2009 Áridos para Hormigón. Available online: https://www.une.org/encuentra-tu-norma/busca-tunorma/norma?c=N0043155 (accessed on 24 May 2021).

49. European Council. 2003/33/EC: Council Decision of 19 December 2002 Establishing Criteria and Procedures for the Acceptance of Waste at Landfills Pursuant to Article 16 of and Annex II to Directive 1999/31/EC; Official Journal of the European Union; European Union: Brussels, Belgium, 2002.

50. Palfy, P.; Vircikova, E.; Molnar, L. Processing of arsenic waste by precipitation and solidification. Waste Manag. 1999, 19, 55-59. [CrossRef]

51. Chintalapati, P.K.; Davis, A.D.; Hansen, M.R.; Sorensen, J.L.; Dixon, D. Encapsulation of limestone waste in concrete after arsenic removal from drinking water. Environ. Earth Sci. 2009, 59, 185-190. [CrossRef]

52. Akhter, H.; Cartledge, F.K.; Roy, A.; Tittlebaum, M.E. Solidification/stabilization of arsenic salts: Effects of long cure times. J. Hazard. Mater. 1997, 52, 247-264. [CrossRef]

53. Dutré, V.; Vandecasteele, C. Immobilization Mechanism of Arsenic in Waste Solidified Using Cement and Lime. Am. Chem. Soc. 1998. [CrossRef]

54. Shih, C.J.; Lin, C.F. Arsenic contaminated site at an abandoned copper smelter plant: Waste characterization and solidification/stabilization treatment. Chemosphere 2003, 53, 691-703. [CrossRef]

55. Jing, C.; Liu, S.; Meng, X. Arsenic leachability and speciation in cement immobilized water treatment sludge. Chemosphere 2005, 59, 1241-1247. [CrossRef]

56. Bhunia, P.; Pal, A.; Bandyopadhyay, M. Assessing arsenic leachability from pulverized cement concrete produced from arsenicladen solid CalSiCo-sludge. J. Hazard. Mater. 2007, 141, 826-833. [CrossRef]

57. Choi, W.H.; Lee, S.R.; Park, J.Y. Cement based solidification/stabilization of arsenic-contaminated mine tailings. Waste Manag. 2009, 29, 1766-1771. [CrossRef]

58. Nastac, D.C.; Fechet, R.; Cristina Năstac, D.; Fechet, R.M. The Influence of Mine Tailings and Oily Sludge on the Portland Cement Clinker Manufacture Influenţa Sterilului Minier Şi A Nămolului De Petrol Asupra Fabricării Clincherului De Ciment Portland The Influence Of Mine Tailings And Oily Sludge On The Portland. Rom. J. Mater. 2017, 47, 176-182.

59. Qiu, G.; Luo, Z.; Shi, Z.; Ni, M. Utilization of coal gangue and copper tailings as clay for cement clinker calcinations. J. Wuhan Univ. Technol. Mater. Sci. Ed. 2011, 26, 1205-1210. [CrossRef] 